\title{
VOLATILITY SPILLOVER AND DYNAMIC CORRELATION BETWEEN THE CARBON MARKET AND ENERGY MARKETS
}

\author{
Yufeng CHEN ${ }^{1,2,3^{*}}$, Fang QU ${ }^{1}$, Wenqi $\mathrm{LI}^{1}$, Minghui $\mathrm{CHEN}^{4}$ \\ ${ }^{1}$ School of Economics, Zhejiang Gongshang University, Hangzhou, China \\ ${ }^{2}$ College of Business Administration, Capital University of Economics and Business, Beijing, China \\ ${ }^{3}$ Center for Studies of Modern Business, Zhejiang Gongshang University, Hangzhou, China \\ ${ }^{4}$ MBA School, Zhejiang Gongshang University, Hangzhou, China
}

Received 21 December 2018; accepted 18 June 2019

\begin{abstract}
This paper studies the volatility spillover and dynamic correlation between EU emission allowance (EUA) prices and energy prices by considering three energy commodities, including oil, gas, and coal. The asymmetric BEKK model is employed for multi-phase analysis of EU ETS, yet only a little empirical evidence backing up the existence of volatility spillover between EU ETS and energy markets, i.e., the establishments of the EU ETS may not effectively restrict and influence energy markets. The time-varying conditional correlation between EUA and each of energy prices is analyzed. The dynamic correlation shows there is a relatively stable, positive correlation between the EUA and Brent oil, natural gas. However, modeling the dynamics correlation also suggests that the correlation between the EUA and the natural gas, coal became weaker and more volatile since second and third phases, especially after the Global Financial Crisis in 2008, which may indicate that the demand reduction in emission allowances caused by the economic slowdown far exceeds the reduction in the annual restraint of EU ETS.
\end{abstract}

Keywords: volatility spillover, EU ETS, EUA, energy price, asymmetric BEKK model, dynamic correlation.

JEL Classification: C32, G12, Q43.

\section{Introduction}

Volatility means risk, and volatility spillover represents risk transfer between diverse financial markets. Understanding the volatility spillover between EU ETS and energy market in various phases has vital reference significance for the establishment and improvement of emission trading schemes in countries around the world. Carbon emission allowance is one of the most essential commodities in the carbon market that is recognized as an efficient way to answer the greenhouse gas (GHG) emission problem. It has been traded on exchanges and Over-The-Counter (OTC) market since the announcement of Kyoto Protocol. The European

*Corresponding author. E-mail: chenyufeng@gmail.com 
Union Emission Trading Scheme (EU ETS) was the first one in the world that was established in 2005 and it is now still the world's largest emission trading scheme, which covers sectors that account for approximately $45 \%$ of Europe's total GHG emissions, and it is the most representative emission trading scheme in the world (Hu, Crijns-Graus, Long, \& Gilbert, 2015). As of 2017, there are 21 operating emissions trading schemes in the world, and economies with an ETS in place produce more than 50\% of global GDP and are home to almost a third of the global population. More countries, including China, United States, Mexico and Brazil start to develop their own emissions trading schemes, which makes the carbon market become one of the most promising markets for investors. Thus, it is necessary and vital for policymakers, regulated energy enterprises and investors to understand the fundamentals of the carbon price and the factors that affect it. Moreover, as more financial corporations and investors are investing the derivatives of the emission allowance, it is useful for them to fully understand the change of volatility behind the prices.

The energy price is one of the important factors since the amount of $\mathrm{CO}_{2}$ emission is associated with what kinds of energy used. The use of crude oil, natural gas, and coal is the main source of $\mathrm{CO}_{2}$ emissions (Fan, Jia, Wang, \& Xu, 2017), and the impact of such energy price on carbon price is extremely significant. Although these commodities may come from different financial markets, their attribute is the same, reflecting the real price of such energy. Specifically, the sharp and sustained increase of energy price and the inelastic demand for energy will induce large demand for emission allowance and hence a higher carbon price. Furthermore, this paper is interested in how the carbon prices response to shocks on the energy prices, which is significant for risk management and portfolio optimization. MansanetBataller, Pardo, and Valor (2007), Alberola, Chevallier, and Chèze (2008a, 2008b), Keppler and Mansanet-Bataller (2010) found empirical evidences showing the prices of energy, electricity and factors like weather and markets' expectation are the leading factors that affect the carbon prices. Recent research has focused on the impact of EU ETS on energy conservation and emission reduction in the aviation sector and energy efficiency management (Cui et al., 2017; Nava, Meleo, Cassetta, \& Morelli, 2018). This is because after January 2012, the aviation sector was forced to be included in the EU ETS and the transportation sector has become a typical purchaser of EU ETS, which they mainly use oil and coal.

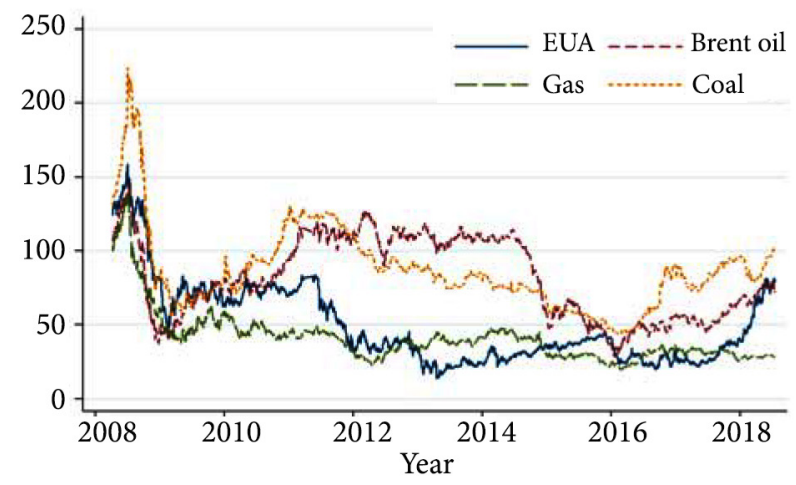

Figure 1. Daily prices of the EUA and the energy 
Meanwhile, after the Global Financial Crisis, a potential fact can be observed from the Figure 1, the oil and the coal prices seem to have a negative trend against the EU emission allowance (EUA) price, and this trend is especially significant during the year 2014 to 2016. From the perspective of financial markets, the emission allowance and energy are alternative investments. In other words, when energy prices rise, energy consumption will declines, which lead to a trend of decline in $\mathrm{CO}_{2}$ emissions, may eventually lead to a fall in the carbon price of the EU ETS. This economic intuition motivates us to reevaluate the correlation between the carbon and energy prices. The volatility spillover is a measure of how much a shock in the price volatility of a financial asset will affect another asset's price. It can also be interpreted as a proxy for information transmitted between two markets and has been widely used in the application and researches of economics and finance (Hamao, Masulis, \& Ng, 1990; Baele, 2005; Du, Yu, \& Hayes, 2011). Moreover, multivariate GARCH models have often been used in previous literature to study the volatility spillover of the energy and carbon markets, and the most representative methods are the BEKK model and the DCC model. Efimova and Serletis (2014) use the data from the energy market to show that the multivariate GARCH model performs well in studying the correlation and spillover effects. Zhang and Sun (2016) explore the volatility spillover between the EU ETS and the fossil energy market using a threshold DCC. Dhamija, Yadav, and Jain (2016) study the volatility of EU ETS and energy prices, and they found that the asymmetric GARCH model is relatively optimal.

Currently, the EU ETS is divided into four phases (phase I: 2005-2007, phase II: 20082012, phase III: 2013-2020), and the fourth phase (2021-2030) has not yet arrived. Thus, this research focuses on the situation of the EU ETS in the I to III Phases so far. EU ETS works on the "cap-and-trade" principle, i.e., the companies' emission is subject to the cap set annually and they receive, buy and sell emission allowances within the scheme. Consequently, the total amount of carbon emissions of the EU ETS remains constant during a trading cycle. The cap of carbon emission is reduced over time so that total emissions fall. So far, EU ETS covers around 45\% of total GHG from 31 countries (all $28 \mathrm{EU}$ countries plus Iceland, Liechtenstein and Norway) and the emission of $\mathrm{CO} 2$ from power plants, a wide range of energy-intensive industry sectors and transportation sector. Since its commencement, a number of researches have begun to discuss the allocation process and the mechanism of the EU ETS (Ellerman, 2008; Ellerman, Convery, \& De Perthuis, 2010; Parsons, Ellerman, \& Feilhauer, 2009; Hu, Crijns-Graus, Long, \& Gilbert, 2015; Dhamija, Yadav, \& Jain, 2016; Jiménez-Rodríguez, 2019) and most studies takes EUA price as the carbon price.

To sum up, compared with the previous literature, the potential contributions of this article are concentrated in the following aspects: Firstly, this paper discusses the correlation and volatility spillover of EU ETS to the energy market on multi-phase perspective. Because of the different operating time of the EU ETS, the economic conditions and trading rules faced by this scheme (EU ETS) in different periods are also diverse. Since many literatures have used the entire cycle or a certain phase of the EU ETS as a research sample (Alberola, Chevallier, \& Chèze, 2008a, 2008b; Chevallier, 2011; Eugenia Sanin, Violante, \& Mansanet-Bataller, 2015; Dhamija, Yadav, \& Jain, 2016; Zhang \& Sun, 2016; Wang \& Guo, 2018), supplementing multi-phase research has practical significance. Secondly, the asymmetric BEKK model is a powerful weapon for the study of volatility spillovers. This model not only measures the 
direction of volatility spillovers, but also can observe the magnitude of volatility. On this basis, this paper considers dynamic correlation and further investigates the fluctuations in the relationship between EU ETS and energy markets from the time-varying perspective. Finally, this paper also examine the asymmetry of the volatility spillover effects between the EU ETS and the energy markets in various phases, which present explanation the impact of economic events on spillover.

The structure of this paper is organized as follows: Section 1 presents the literature review. The data and the models employed are described in section 2 and section 3 . In section 4 , this paper provides the empirical results and analysis. The section 5 is a discussion of details. Conclusions, policy implications and the further research are shown by final section.

\section{Literature review}

It is widely accepted that the $\mathrm{CO}_{2}$ emission allowance price is related to energy prices, temperature condition and power prices (Mansanet-Bataller, Pardo, \& Valor, 2007; Keppler \& Mansanet-Bataller, 2010; Chevallier, 2011; Aatola, Ollikainen, \& Toppinen, 2013; Eugenia Sanin, Violante, \& Mansanet-Bataller, 2015; Kanamura, 2016; Lin \& Jia, 2017; Fan, Jia, Wang, \& Xu, 2017; Soliman \& Nasir, 2018; Dutta, Bouri, \& Noor, 2018). Mansanet-Bataller, Pardo, and Valor (2007) used daily data in the OLS regression and found daily CO2 emission price change was related to the price changes of crude oil, natural gas and extremely hot and cold temperature in German. Alberola, Chevallier, and Chèze (2008a) used daily spot data and extended the previous literature by considering structural breaks, finding the energy fundamentals and extremely cold temperature does have impacts on the price changes. Different from the previous findings, Aatola, Ollikainen, and Toppinen (2013) built an equilibrium model of the emission trading market and tested it with daily forward data using OLS, IV and VAR models. Their results show there is a clear and stable correlation between the fundamentals and the price of EUA. Except for energy, temperature and power prices, Alberola, Chevallier, and Chèze (2008b) first showed three industries' production (combustion, paper, and iron) has a large impact on EUA price changes using linear regression and TGARCH model. Using a supply and demand based correlation model, Kanamura (2016) report a positive energy price impact on EUA prices. Ibrahim and Kalaitzoglou (2016) proposed an asymmetric information microstructural pricing model in which price responses to information and liquidity vary with every transaction and find that expected trading intensity to simultaneously increase the information component and decrease the liquidity component of price changes.

Some of researches have started to characterize EUA price volatility that is meaningful in the financial application such as risk management and carbon pricing. Benz and Trück (2009) found that regime-switching or GARCH model are the best to capture the dynamic behavior and volatility of EUA returns, which is very helpful for risk management and cost control. Chevallier (2011) extended that Benz and Trück's (2009) by taking other fundamental drivers of the carbon price into account and found the economic activity is a key determinant of the carbon price returns. Lutz, Pigorsch, and Rotfuß (2013) analyzed the nonlinearity correlation between EUA price and its fundamentals by considering regime-switching into 
a GARCH type model and characterizing their time-varying influence. Conrad, Rittler, and Rotfuß (2012) chose high-frequency data and applied a fractional integrated asymmetric power GARCH model to show conditional heteroscedasticity and long memory property of EUA returns, which is crucial in financial practice. Xu, Deng, and Thomas (2016) investigate the impact of financial options on reducing carbon permit price volatility under a cap-andtrade system and report that introducing financial options in a banking environment offers more flexibility to risk management in carbon permit trading. Campiglio (2016) argues carbon pricing in itself may not be sufficient and discusses the potential role of monetary policies and macroprudential financial regulation.

Many studies used the exchange rate in financial markets as the research object to explore its volatility and spillover effects (Akar, 2017; Bubák, Kocenda, \& Zikes, 2011; Hong, 2001). The employ of high-frequency data and spillover index is also the mainstream scheme on research of volatility (Chen, $\mathrm{Li}, \& \mathrm{Qu}, 2019$ ). These studies have played a pioneering role in applying volatility to the discussion of carbon trading schemes. However, as the interaction among different financial markets is unsteady, forecasting volatility should take other variables into consideration. A few pieces of research have discussed mutual interaction and volatility spillover between EUA market and fundamentals. Fezzi and Bunn (2009) used a structural and co-integrated vector error-correction model (VECM) to consider the possible mutual interaction between gas, carbon, and power which first provide a framework that included both long-run equilibrium and short-term effects. Reboredo (2014) proposed a MCARR model to capture this effect between oil market and EUA market using daily prices of EUA future and found no spillover between them. Mansanet-Bataller and Soriano (2009) applied BEKK model proposed by Engle and Kroner (1995) to characterize the volatility transmission among oil natural gas and EUA market. In contrast to Reboredo (2014), Mansanet-Bataller and Soriano (2009) found bidirectional volatility transmission between oil and EUA price and the natural gas market has unidirectional volatility transmission to the other markets. Wang and Guo (2018) employ the spillover index constructed by Diebold and Yilmaz $(2009,2012)$ to investigate the asymmetric volatility spillover effect between the carbon market and three energy prices including WTI oil, Brent oil and EU natural gas. Ji, Zhang, and Geng (2018) considers the correlation between electricity prices and the carbon market and believe the electricity prices to be the mainly recipient of information transfer. Overall, most studies have considered significant volatility spillover effects between the EUA market and other financial markets.

It can be found that carbon emissions as a special financial commodity, most of the previous research from the financial point of view, using time series analysis method (VAR, VECM, GARCH type, BEKK and so on) to discuss the correlation and mean or volatility spillover effect between carbon market and energy markets. Regrettably, few studies have focused on coal market because the proportion of coal in primary energy consumption in Europe has already fallen dramatically. But for developing countries such as China, Brazil and India, the proportion of coal in primary energy consumption is still high, and considering coal is an important reference value for these countries. Therefore, this paper extends the previous studies by taking coal price and discussing the dynamic volatility spillover between the traditional energy markets and EUA market. 


\section{Data}

The EUA daily future price from the European Climate Exchange (ECX) is used as the carbon price. For the oil, coal and gas price, the price of the Brent future contract and the Rotterdam Coal future price from the International Petroleum Exchange (IPE), and the price of gas future contracts from NYMEX, were selected as research samples. All data series have been collected from WIND Information Financial database.

As shown in the Figure 2, in the phase I of the EU ETS, the price of EUA future followed two major slowdowns. One occurred in April 2006 because the announcement of verified emission amount implied an over-allocation of EUA. The other slump, at the end of the phase I, resulted from not only over-allocation but also the banking restriction, leading to selling-off and price collapse (Parsons, Ellerman, \& Feilhauer, 2009; Zhang \& Wei, 2010). The variance of EUA returns was very large after December 17, 2007 because of the adjustment by authority, so this paper decides to discard the data after that date to get a stationary series.

In addition, because of the availability of the coal data, this paper analyze the existence of spillover between EUA with oil and EUA with natural gas and their dynamic correlation during the phase I, and the data from April 22, 2005 to December 17, 2007. For the analysis of the II and the III phase, the sample data is from April 08, 2008 to December 31, 2012 that covers almost all second period of the EU ETS and January 2, 2013 to July 17, 2018 that is the phase III so far. All price series are converted into euro using exchange rates from European Central Bank in order to remove the effect of exchange rate variability. Therefore, the data period and the number of observations are shown in Table 1. The log returns are calculated as follows: $r_{t}=100 \times \ln \left(P_{t} / P_{t-1}\right)$. $P$ uses the settle price for all series. These data periods contain several important periods in which the energy markets experienced a large instability, for example, Global Financial Crisis in 2008 and oil price slowdown in 2015.

Figure 3 and 4 display the returns of the EUA, Brent oil, natural gas and coal from phase II and phase III. All returns series show volatility clustering. Table 2 presents the summary statistics of all the log returns of EUA and energy in three phases of the EU ETS. The augmented stationarity test (ADF, PP and KPSS) shows all series are stationary. The similar mean value is displayed, but differs in the standard deviation of series from phase to phase. The log returns of EUA have the largest standard deviation in the first and the third phase, while the log returns of natural gas have the largest standard deviation in the second phase. The

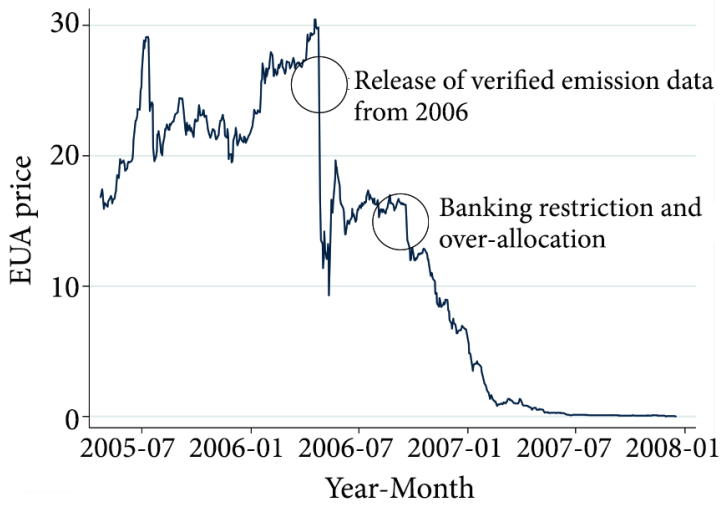

Figure 2. Daily EUA Price from the phase I of EU ETS 
skewness, kurtosis as well as Jarque-Bera test show that only the log returns of Brent in the first phase follow the normal distribution. The log returns of EUA have large kurtosis and Jarque-Bera statistic in the first phase, which results from large instability. The Ljung-Box test of the four series has different results from each other. Even the same series have inconsistent test results in different phases. The Q statistic shows that the log returns of EUA are autocorrelated in the first to third phase. The coal and natural gas returns are autocorrelated only in the second. This may be due to the grouping of samples, and it does not indicate that these series do not have autocorrelation in the long run.

Table 1. Phase of EU ETS and the Number of Observation

\begin{tabular}{|c|c|c|c|}
\hline Phases & Start & End & Number of Observation \\
\hline Phase I & 2005.04 .22 & 2007.12 .17 & 661 \\
\hline Phase II & 2008.04 .08 & 2012.12 .31 & 1180 \\
\hline Phase III & 2013.01 .02 & 2018.07 .17 & 1383 \\
\hline
\end{tabular}
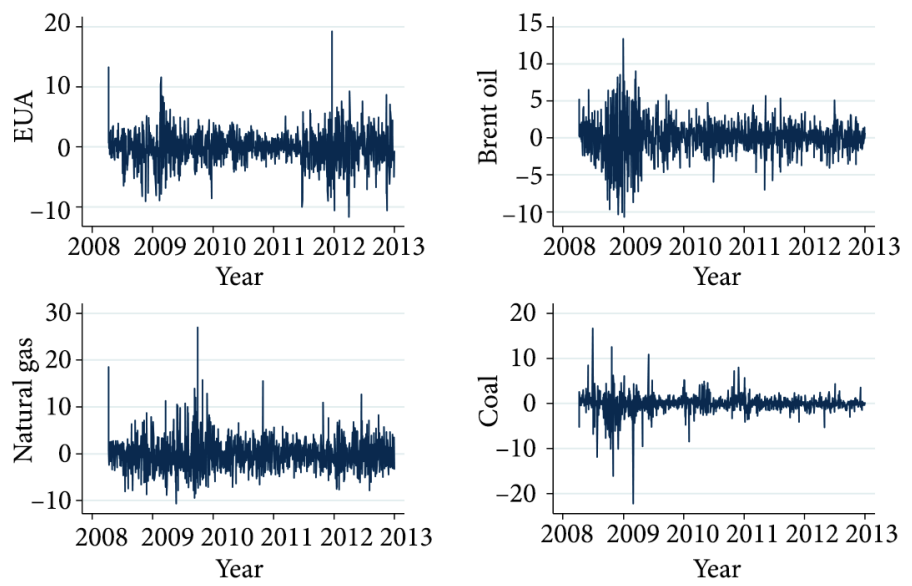

Figure 3. Daily Log Returns of EUA and the Energy Futures from the phase II of EU ETS
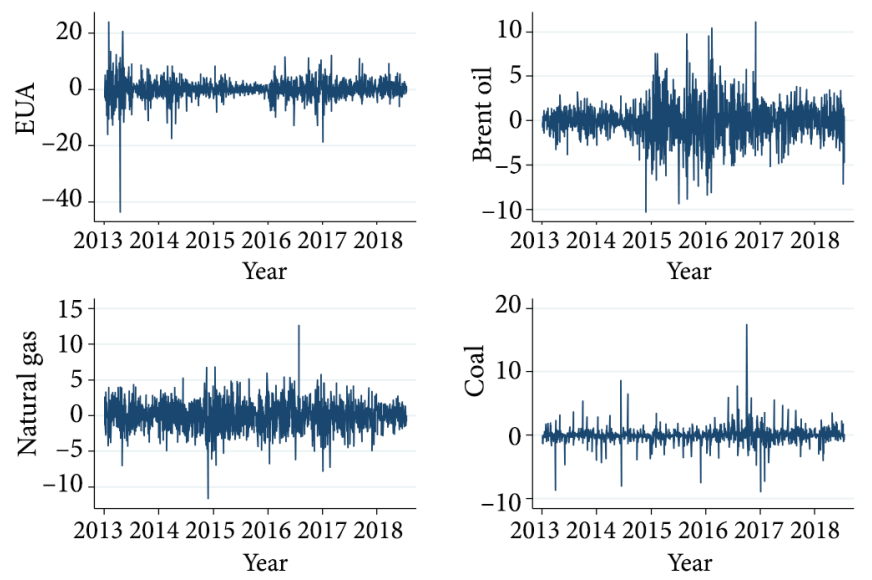

Figure 4. Daily Log Returns of EUA and the Energy Futures from the phase III of EU ETS 
Table 2. Descriptive Statistics for the Daily Log Returns of the EUA and the Energy Futures

\begin{tabular}{|c|c|c|c|c|}
\hline Phase I & Brent & gas & EUA & \\
\hline Mean & 0.06 & -0.02 & -1.12 & \\
\hline Std. dev & 1.74 & 3.70 & 10.84 & \\
\hline Skewness & -0.09 & 0.69 & -3.11 & \\
\hline Kurtosis & 3.16 & 7.58 & 74.90 & \\
\hline J-B test & 1.61 & $633.39^{* * *}$ & $143899.83^{* * *}$ & \\
\hline ADF test & $-28.467^{* * *}$ & $-25.351^{* * *}$ & $-26.727^{* * *}$ & \\
\hline PP test & $-28.479^{* * *}$ & $-25.368^{* * *}$ & $-26.742^{* * *}$ & \\
\hline KPSS & 0.09 & 0.09 & 0.09 & \\
\hline $\mathrm{Q}(5)$ & $14.12^{* *}$ & 1.06 & $15.557^{* * *}$ & \\
\hline $\mathrm{Q}(10)$ & $15.63^{* *}$ & 2.18 & $31.150^{* * *}$ & \\
\hline Observation & 661 & 661 & 661 & \\
\hline Phase II & Brent & gas & coal & EUA \\
\hline Mean & 0.02 & -0.06 & -0.02 & -0.10 \\
\hline Std. dev & 2.27 & 3.48 & 2.01 & 2.74 \\
\hline Skewness & -0.20 & 1.04 & -0.88 & 0.13 \\
\hline Kurtosis & 6.63 & 8.32 & 27.28 & 6.91 \\
\hline J-B test & $663.25^{* * *}$ & $1615.66^{* * *}$ & $30945.47^{* * *}$ & $759.58^{* * *}$ \\
\hline ADF test & $-36.75^{* * *}$ & $-38.74^{* * *}$ & $-32.95^{* * *}$ & $-8.73^{* * *}$ \\
\hline $\mathrm{PP}$ test & $-36.82^{* * *}$ & $-38.76^{* * *}$ & $-33.01^{* * *}$ & $-32.41^{* * *}$ \\
\hline KPSS & 0.14 & 0.06 & 0.18 & 0.06 \\
\hline $\mathrm{Q}(5)$ & $10.46^{*}$ & $26.20^{* * *}$ & $22.19^{* * *}$ & $10.68^{*}$ \\
\hline $\mathrm{Q}(10)$ & $21.11^{* *}$ & $40.21^{* * *}$ & $46.77^{* * *}$ & $20.75^{* *}$ \\
\hline Observation & 1180 & 1180 & 1180 & 1180 \\
\hline Phase III & Brent & gas & coal & EUA \\
\hline Mean & -0.03 & -0.01 & 0.01 & 0.07 \\
\hline Std. dev & 2.05 & 1.97 & 1.23 & 3.52 \\
\hline Skewness & 0.09 & -0.06 & 1.70 & -1.35 \\
\hline Kurtosis & 6.82 & 5.32 & 43.22 & 24.06 \\
\hline J-B test & $843.99^{* * *}$ & $311.28^{* * *}$ & $93817.01^{* * *}$ & $25968.64^{* * *}$ \\
\hline ADF test & $-40.560^{* * *}$ & $-38.249^{* * *}$ & $-36.470^{* * *}$ & $-38.098^{* * *}$ \\
\hline PP test & $-40.444^{* * *}$ & $-38.261^{* * *}$ & $-36.520^{* * *}$ & $-38.186^{* *}$ \\
\hline KPSS & 0.31 & 0.07 & 0.35 & 0.23 \\
\hline $\mathrm{Q}(5)$ & $17.04^{* * *}$ & 2.14 & 4.86 & $48.23^{* * *}$ \\
\hline $\mathrm{Q}(10)$ & $18.31^{* *}$ & 7.50 & 13.69 & $67 \cdot 10^{* * *}$ \\
\hline Observation & 1383 & 1383 & 1383 & 1383 \\
\hline
\end{tabular}

${ }^{\star},{ }^{* *}$ and ${ }^{* *}$ represent the statistics are significant in the confidence level of $10 \%, 5 \%$ and $1 \%$. 


\section{Methodology}

Based on the BEKK model proposed by Engle and Kroner (1995), which is not only to measures the direction of volatility spillovers, but it also can observe the magnitude of volatility spillover. In addition, in order to investigate the asymmetry of volatility spillover, this paper further employ the asymmetric BEKK mothed to analyze the spillover effect between the EU ETS and energy market, which can explore to what type of news (good or bad) the volatility spillovers between EU ETS and energy markets in different phases is more sensitive.

Let $r_{t}$ denote the asset's returns, the typical BEKK model can be shown as follows:

$$
\begin{gathered}
r_{t}=\mu+e_{t} ; \\
e_{t} \mid I_{t-1} \sim \operatorname{std}\left(0, H_{t}\right) ; \\
H_{t}=C_{0} C_{0}^{T}+\sum_{i=1}^{p} A_{i}\left(e_{t-i} e_{t-i}^{T}\right) A_{i}^{T}+\sum_{j=1}^{q} B_{j} H_{t-j} B_{j}^{T},
\end{gathered}
$$

Where $\mu$ is a vector of constant of mean value. $e_{t}$ is a vector of residual terms, which is the source of volatility and risk. $I_{t-1}$ is the information set generated by the past values $e_{t}$. Where $A_{i}$ and $B_{j}$ are unrestricted $k \times k$ parameter matrices with $C_{0}$ triangular. Assuming that the $e_{t}$ follows the normal distribution in conditional of the past information. The conditional variance $H_{t}$ follows a BEKK model. It is easy to show that $H_{t}$ is guaranteed to be symmetric and positive semi-definite in the above formulation because $C_{0} C_{0}^{T}$ is positive definite. Eq. (1) to (3), the Eq. (1) is called the mean equation. For series with autocorrelation, Eq. (1) is assumed to be a vector autoregressive (VAR) structure as follows:

$$
r_{i, t}=\alpha_{i}+\sum_{k=1}^{p} \Omega_{k} r_{i, t-k}+e_{i, t} .
$$

Where $\alpha$ is the $k$ dimensional constant, $\Omega$ is the $k \times k$ parameter matrix, and $e_{t}$ should satisfy independent and identical distribution (i.i.d), consistent with Eq. (2). The Eq. (3) is called the variance equation, and the $e_{t}$ in Eq. (2) is used to create Eq. (3). Besides, the BEKK model requires estimation of $(p+q) k^{\wedge} 2+k(k+1) / 2$ parameters as the increase of the number of $k, p$ and $q$. The $p$ and $q$ are representing the level of the ARCH effect and the GARCH effect. In order to avoid the problem of dimensional curse on BEKK model, this paper consider the typical BEKK model with $p=q=1$. In order to further consider the asymmetry of volatility spillover, connected with the concept of GJR-GARCH model (Glosten, Jagannathan, \& Runkle, 1993; Zhang \& Sun, 2016), the following asymmetric $\operatorname{BEKK}(1,1)$ model is employed:

$$
H_{t}=C_{0} C_{0}^{T}+A_{1}\left(\mathbf{e}_{t-1} \mathbf{e}_{t-1}^{T}\right) A_{1}+B_{1} H_{t-1} B_{1}^{T}+D_{1}\left(z_{t-1} z_{t-1}^{T}\right) D_{1} .
$$

The form of the $D$ matrix is the same as the $A$ and $B$ matrices, and $z_{t-1}$ is a $k$ dimensional column vector. When $e_{t-1}$ is negative ( $e_{t-1} \leq 1$ it means bad news or negative shock), the $z_{t-1}=e_{t-1}$, else, $z_{t-1}=0$. Consequently, the matrix $D$ measures the asymmetric effects between the EU ETS and the energy markets. Moreover, many studies believe that there are 
fat tails facts in financial assets (Akar, 2017; Bubák et al., 2011), so the model of asymmetric $\operatorname{BEKK}(1,1)$ consider that the residual terms follow the distribution of normal, skewed-normal and student-t. According to the Log-Likelihood and Akaike information criterion (AIC) values, the estimation result of the model is best when the series residuals follow the student- $t$ distribution.

In the bivariate case, the asymmetric $\operatorname{BEKK}(1,1)$ model becomes:

$$
\begin{aligned}
\sigma_{11, t}^{2}= & c_{11}^{2}+c_{12}^{2}+\alpha_{11}^{2} e_{1 . t-1}^{2}+2 \alpha_{11} \alpha_{12} e_{1, t-1} e_{2, t-1}+\alpha_{12}^{2} e_{2, t-1}^{2}+ \\
& \beta_{11}^{2} \sigma_{11, t-1}^{2}+2 \beta_{11} \beta_{12} \sigma_{12, t-1}^{2}+\beta_{12}^{2} \sigma_{22, t-1}^{2}+ \\
& d_{11}^{2} z_{1, t-1}^{2}+2 d_{11} d_{21} z_{1, t-1} z_{2, t-1}+d_{21}^{2} z_{2, t-1}^{2} ; \\
\sigma_{12, t}^{2}= & c_{12} c_{22}+\alpha_{11} \alpha_{21} e_{1, t-1}^{2}+\left(\alpha_{21} \alpha_{12}+\alpha_{11} \alpha_{22}\right) e_{1, t-1} e_{2, t-1}+\alpha_{21} \alpha_{22} e_{2, t-1}^{2}+ \\
& \beta_{11} \beta_{21} \sigma_{11, t-1}^{2}+\left(\beta_{21} \beta_{11}+\beta_{11} \beta_{22}\right) \sigma_{12, t-1}^{2}+\beta_{12} \beta_{22} \sigma_{22, t-1}^{2}+ \\
& d_{11} d_{12} z_{1, t-1}^{2}+\left(d_{12} d_{21}+d_{11} d_{22}\right) z_{1, t-1} z_{2, t-1}+d_{21} d_{22} z_{2, t-1}^{2} ; \\
\sigma_{22, t}^{2}= & c_{22}^{2}+\alpha_{21}^{2} e_{1 . t-1}^{2}+2 \alpha_{21} \alpha_{22} e_{1, t-1} e_{2, t-1}+\alpha_{22}^{2} e_{2, t-1}^{2}+ \\
& \beta_{21}^{2} \sigma_{11, t-1}^{2}+2 \beta_{21} \beta_{22} \sigma_{12, t-1}^{2}+\beta_{22}^{2} \sigma_{22, t-1}^{2}+ \\
& d_{12}^{2} z_{1, t-1}^{2}+2 d_{12} d_{22} z_{1, t-1} z_{2, t-1}+d_{22}^{2} z_{2, t-1}^{2} .
\end{aligned}
$$

Where $c_{i j}, \alpha_{i j}$ and $\beta_{i j}$ is the $i j$ element of matrix $C_{0}, A_{1}$ and $B_{1}$. The $A$ matrix reflects the ARCH effect, and the $B$ matrix reflects the GARCH effect. If the non-diagonal elements of $A_{1}$ and $B_{1}$ is zero or non-significant, especially $B_{1}$, the two series does not have a volatility spillover effect on each other. The $d_{i i}$ and $d_{i j}(i \neq j)$ come from matrix $D_{1}$, which reflect the magnitude and direction of the asymmetry effect.

Finally, the conditional variance of two return series can be derived from the bivariate asymmetry BEKK model. Then this paper calculates the conditional correlation between them, also referred as dynamic correlation, by the following equation:

$$
\rho_{t}=\frac{\sigma_{12, t}^{2}}{\sigma_{11, t} \sigma_{22, t}} .
$$

The dynamic correlation $\left(\rho_{t}\right)$ provides us a dynamic perspective to see the changes in the relationship between EUA and energy variables in the past decade, which may have a different finding from the previous literature. Estimation of the asymmetric BEKK model was done using winrats 8 .

\section{Empirical results}

\subsection{Phase I of EU ETS}

The first trading phase was a three-year pilot period started from 2005, a "learning by doing" period prepared for the second phase. In this phase the EU ETS only included $\mathrm{CO}_{2}$ emission from power generators and energy-intensive industries. Through National Allocation Plans (NAPs), it set a cap on allowances at a national level. Phase I succeeded in establishing a "cap-and-trade" institution and pricing the $\mathrm{CO}_{2}$ emissions. 
Table 3. Estimation of asymmetric BEKK $(1,1)$ Model to the Daily Log Returns of EUA and Brent, Natural gas from 22/4/2005 to 17/12/2007 for 661 Observations

\begin{tabular}{|c|c|c|c|c|}
\hline \multirow{3}{*}{ Parameters } & \multicolumn{4}{|c|}{$\begin{array}{c}\text { Estimations } \\
\text { (Standard Errors) }\end{array}$} \\
\cline { 2 - 5 } & \multicolumn{3}{|c|}{ EUA-Brent } & \multicolumn{2}{c|}{ EUA-gas } \\
\hline \multirow{4}{*}{$C_{0}$} & $0.5199^{*}$ & & $(0.1907)$ & 0.0001 \\
& $(0.2993)$ & 0.0001 & $0.6325^{* * *}$ & $(1.3196)$ \\
\cline { 2 - 5 } & $1.9937^{* * *}$ & $(3.2434)$ & $(0.1669)$ & 0.0060 \\
& $(0.1149)$ & 0.0123 & $0.6357^{* * *}$ & $(0.0135)$ \\
\hline \multirow{4}{*}{$A_{1}$} & $0.5411^{* * *}$ & $(0.0124)$ & $(0.1114)$ & $0.1958^{* * *}$ \\
& $(0.0887)$ & -0.0073 & -0.0262 & $0.0482)$ \\
\cline { 2 - 5 } & 0.1143 & $(0.1402)$ & $(0.0682)$ & 0.0241 \\
& $(0.1146)$ & -0.0049 & $0.7344^{* * *}$ & $(0.0343)$ \\
\hline \multirow{3}{*}{$B_{1}$} & $0.7403^{* * *}$ & $(0.0126)$ & -0.0683 & $0.9701^{* * *}$ \\
& $(0.0290)$ & $0.0427^{*}$ & $(0.0551)$ & $(0.0080)$ \\
\cline { 2 - 5 } & 0.2190 & $(0.3615)$ & $0.8071^{* * *}$ & 0.0125 \\
& $(0.1312)$ & 0.0101 & $(0.1398)$ & $(0.0158)$ \\
\hline \multirow{3}{*}{$D_{1}$} & $0.8184^{* * *}$ & $(0.0127)$ & 0.0386 & $-0.2573^{* * *}$ \\
& $(0.1173)$ & $0.3615^{* * *}$ & $(0.0794)$ & $(0.0769)$ \\
\cline { 2 - 5 } & $-0.7078^{* * *}$ & $(0.1401)$ & & -3682.259 \\
\hline \multirow{2}{*}{ Log Likelihood } & $(0.0127)$ & -3234.366 & & \\
\hline
\end{tabular}

${ }^{\star},{ }^{* *}$ and ${ }^{\star * *}$ represent the statistics are significant in the confidence level of $10 \%, 5 \%$ and $1 \%$.

Table 3 presents the estimation results of asymmetric BEKK model for the EUA and Brent oil, natural gas for the phase I of EU ETS. The empirical result indicates that the volatility of EUA returns in the first phase is significantly affected by its own, reflected by the $\beta_{11}$ in both bivariate models. The coefficient of $\beta_{11}$ (0.7403 in EUA-Brent, and 0.7344 in EUA-gas) are large and statistically significant, it indicates that during this phase, its own hysteretic volatility has a strong persistence effect on future volatility. For most financial products, the lag order has a certain impact on the current price, and the previous volatility will also affect the current volatility. $\beta_{21}$ and $\beta_{12}$, the coefficients of cross-product terms of, are indicators for risk and shock transmission between the price of energy and EUA price, which can be referred as volatility spillover effect. However, Table 3 shows neither of the coefficients $\left(\beta_{21}\right.$ and $\beta_{12}$ ) is statistically significant in both models, which indicates that there is no volatility transmission from Brent or natural gas market or vice versa in the first period. The asymmetric coefficient ( $d_{11}$ and $d_{22}$ ) in both models are significant, which indicate that the volatility of the EUA, Brent crude oil and natural gas are asymmetry. However, this asymmetry is not consistent. The asymmetry coefficients of EUA and Brent oil are positive $\left(d_{11}\right.$ and $d_{22}$ in EUA-Brent), which can be explained as bad news increasing their volatility, while the natural gas is the opposite ( $d_{22}$ in EUA-gas). Although the asymmetry coefficient $d_{21}(-0.7078)$ is negative and significant in the EUA-Brent, it has no explanatory power since the volatility of the EUA price does not spillover to Brent oil. 

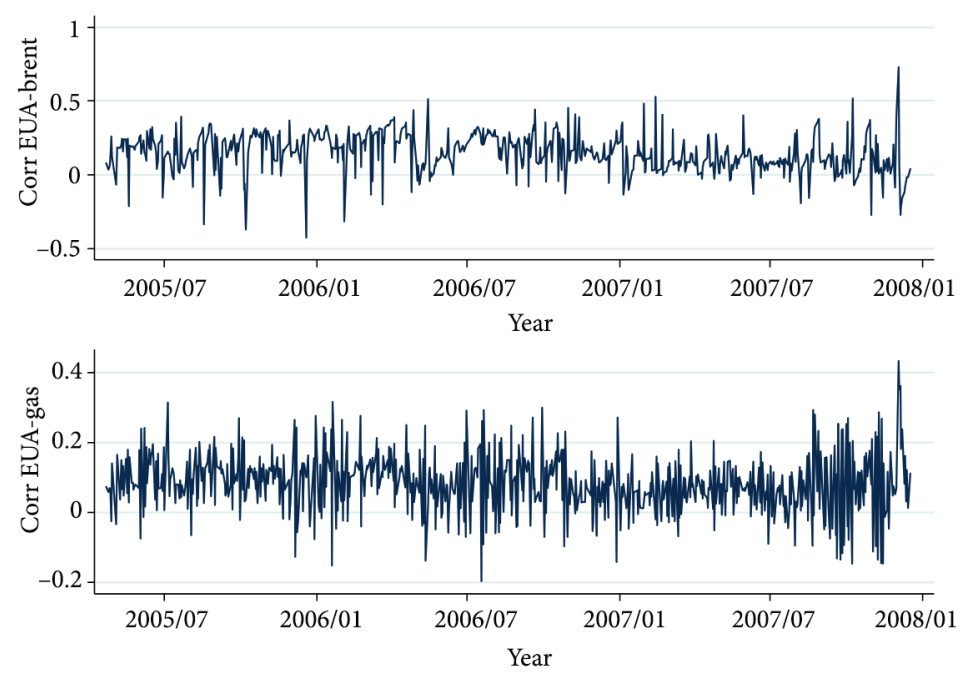

Figure 5. Dynamic correlation between the daily log returns of EUA and the energy futures from the phase I of EU ETS

The dynamic correlation, which can be shown by Figure 5, extends the previous researches about the correlation of EUA and the energy fundamentals. There is a positive correlation between the EUA and the energy futures in the first phase, but the correlation is not stable. The mean value of correlation coefficient between the EUA and Brent oil is around 0.16, while the EUA and natural gas is around 0.08. But the dynamic correlation between EUA and natural gas is more volatile since the range of it is larger. After 2007, the correlation between EUA and Brent oil is still positive overall. However, the correlation between EUA and gas has been experienced large fluctuations, while the mean of correlation after 2007 is 0.007 . It can be considered that EUA and gas have little correlation during this period. The intuition behind this result is because an unofficial announcement about the over-allocation in 2006 caused a large and quick drop in the EUA prices and the price volatility became very large during this period. The dynamic correlation showed there is a weak and positive correlation between the EUA and energy, which is consistent with the results of previous researches (Mansanet-Bataller, Chevallier, \& Chèze, 2007; Alberola, Chevallier, \& Chèze, 2008a; Keppler \& Mansanet-Bataller, 2010; Chevallier, 2011; Aatola, Ollikainen, \& Toppinen, 2013; Wang \& Guo, 2018). In the first phase, however, the correlation between EUA and energy is much lower than the general economic intuition.

\subsection{Phase II of EU ETS}

Phase II was from January 2008 to December 2012 and happened to be coincident with the commitment of Kyoto Protocol. During this phase, EU ETS has undergone some changes in emissions categories, participating countries, and pollution emission limits. First of all, the three EEA-EFTA states (Iceland, Liechtenstein and Norway) joined the EU ETS at the beginning of second phase, it is a step to internationalization. Second, the system also covered nitrous oxide emission from the production of nitric acid by a number of Member states 
and aviation sector was covered from the end of the phase. Third, the free allocation was reduced to at least $90 \%$, while others were allocated by auction. Business was also allowed to buy international Clean Development Mechanism (CDM) and Joint Implementation (JI) credits from emission-saving projects around the world instead of buying allowances to cover its emission.

Table 4. Estimation of asymmetric BEKK $(1,1)$ Model to the daily log returns of EUA and brent, natural gas, coal from $08 / 04 / 2008$ to $31 / 12 / 2012$ for 1180 observations

\begin{tabular}{|c|c|c|c|c|c|c|}
\hline \multirow{2}{*}{ Parameters } & \multicolumn{6}{|c|}{ Estimations (Standard Errors) } \\
\hline & \multicolumn{2}{|c|}{ EUA-Brent } & \multicolumn{2}{|c|}{ EUA-gas } & \multicolumn{2}{|c|}{ EUA-coal } \\
\hline \multirow{2}{*}{$C_{0}$} & $\begin{array}{l}0.2719^{* * *} \\
(0.0684)\end{array}$ & & $\begin{array}{l}0.2929^{* *} \\
(0.0773)\end{array}$ & & $\begin{array}{l}0.2572^{* * *} \\
(0.0610)\end{array}$ & \\
\hline & $\begin{array}{l}-0.1305 \\
(0.0784)\end{array}$ & $\begin{array}{l}0.1477^{* *} \\
(0.0791)\end{array}$ & $\begin{array}{l}-0.0927 \\
(0.1366)\end{array}$ & $\begin{array}{c}0.1203 \\
(0.2208)\end{array}$ & $\begin{array}{c}0.0488 \\
(0.0589)\end{array}$ & $\begin{array}{c}0.1867^{* * *} \\
(0.0424)\end{array}$ \\
\hline \multirow{2}{*}{$A_{1}$} & $\begin{array}{l}0.2690^{* * *} \\
(0.0444)\end{array}$ & $\begin{array}{c}0.0118 \\
(0.0166)\end{array}$ & $\begin{array}{l}0.2543^{* * *} \\
(0.0379)\end{array}$ & $\begin{array}{c}-0.0570^{* *} \\
(0.0268)\end{array}$ & $\begin{array}{l}0.1834^{* * *} \\
(0.0301)\end{array}$ & $\begin{array}{c}0.0060 \\
(0.0181)\end{array}$ \\
\hline & $\begin{array}{l}-0.0601 \\
(0.0367) \\
\end{array}$ & $\begin{array}{l}0.1205^{* *} \\
(0.0511)\end{array}$ & $\begin{array}{c}0.0125 \\
(0.0375) \\
\end{array}$ & $\begin{array}{c}0.0500 \\
(0.0661)\end{array}$ & $\begin{array}{c}0.0588^{*} \\
(0.0349)\end{array}$ & $\begin{array}{l}0.2261^{* * *} \\
(0.0161)\end{array}$ \\
\hline \multirow{2}{*}{$B_{1}$} & $\begin{array}{l}0.9423^{* * *} \\
(0.0113)\end{array}$ & $\begin{array}{l}-0.0005 \\
(0.0053) \\
\end{array}$ & $\begin{array}{l}0.9369^{* * *} \\
(0.0121)\end{array}$ & $\begin{array}{l}0.0140^{* *} \\
(0.0101)\end{array}$ & $\begin{array}{l}0.9604^{* * *} \\
(0.0029)\end{array}$ & $\begin{array}{l}-0.0014 \\
(0.0032) \\
\end{array}$ \\
\hline & $\begin{array}{l}0.0318^{* * *} \\
(0.0095)\end{array}$ & $\begin{array}{l}0.9716^{* * *} \\
(0.0067)\end{array}$ & $\begin{array}{c}0.0104 \\
(0.0075) \\
\end{array}$ & $\begin{array}{l}0.9829^{* * *} \\
(0.0066)\end{array}$ & $\begin{array}{l}-0.0051 \\
(0.0110) \\
\end{array}$ & $\begin{array}{l}0.9622^{* * *} \\
(0.0095)\end{array}$ \\
\hline \multirow[b]{2}{*}{$D_{1}$} & $\begin{array}{l}0.2240^{* * *} \\
(0.0713)\end{array}$ & $\begin{array}{c}0.0187 \\
(0.0195)\end{array}$ & $\begin{array}{l}0.2713^{* * *} \\
(0.0550)\end{array}$ & $\begin{array}{c}0.0560 \\
(0.0408)\end{array}$ & $\begin{array}{l}0.3318^{* * *} \\
(0.0467)\end{array}$ & $\begin{array}{l}-0.0014 \\
(0.0181)\end{array}$ \\
\hline & $\begin{array}{l}-0.0212 \\
(0.0521) \\
\end{array}$ & $\begin{array}{c}-0.2518^{* * *} \\
(0.0444)\end{array}$ & $\begin{array}{c}0.0392 \\
(0.0371) \\
\end{array}$ & $\begin{array}{c}-0.2638^{* * *} \\
(0.0376)\end{array}$ & $\begin{array}{c}0.0213 \\
(0.0573) \\
\end{array}$ & $\begin{array}{l}-0.0168 \\
(0.0545) \\
\end{array}$ \\
\hline $\begin{array}{c}\text { Log } \\
\text { Likelihood }\end{array}$ & \multicolumn{2}{|c|}{-5189.564} & \multicolumn{2}{|c|}{-5687.368} & \multicolumn{2}{|c|}{-4720.435} \\
\hline
\end{tabular}

${ }^{*},{ }^{* *}$ and ${ }^{* * *}$ represent the statistics are significant in the confidence level of $10 \%, 5 \%$ and $1 \%$.

Table 4 presents the estimation results of asymmetric BEKK model to the daily log returns of EUA and three energy prices (Brent, natural gas, and coal) in phase II of the EU ETS. The results are similar to the first phase for other prices (Brent and gas). Still, the coefficient $\beta_{11}$ and $\beta_{22}$ of the $B$ matrix in all models are statistically significant and close to 1 , indicating that past volatility has high persistence in the contemporary and future volatility of EUA returns, it proved that the EUA and energy markets has the significant GARCH effect. In EUA-Brent, the coefficient $\beta_{21}$ (0.0318) becomes significant under the level of $1 \%$, which indicates that there is a volatility spillover from the carbon market to the Brent oil. In EUA-gas, it is interesting that $\beta_{12}(0.0140)$ is statistically significant but $\beta_{21}$ turns to be insignificant, which means there is a volatility spillover from the natural gas to EUA. At last, the volatility spillover does not exist between the EUA and the coal. This can be explained that due to the restrictions of the Kyoto Protocol, the use of coal in EU has fallen sharply, which directly leads to the weakening of the influence of coal prices. From the coefficients of $d_{22}$ in EUA- 
coal, the coal market with no asymmetry effect has been confirmed. The volatility of EUA, Brent oil and natural gas is asymmetric, but the asymmetry effect of Brent oil has changed dramatically compared to the phase I of EU ETS. During this time (2008-2012), Brent oil is more sensitive to good news.

Figure 6 shows the dynamic correlation between EUA and three energy prices. Compared with the correlation between EUA and Brent oil and gas considered in the first phase, there are some changes between each pair. In general, all dynamic correlations in this period became more volatile than the previous phase. The correlation between the EUA and Brent oil returns was positive in most of the time during this phase, and its mean value of correlation coefficient is 0.19 , similar with the first phase, rather than the period when the prices slumped. The dynamic correlation between EUA and coal also had a similar evolution during this phase. What is interesting is the correlation of EUA and coal dropped to be negative during most of the period. Another result is that the mean value of correlation coefficient between the EUA and the natural gas fluctuates around 0.01, which may indicate that the correlation between EUA and natural gas is unstable. This result somehow contrasts with the previous literatures that natural gas is one of the fundamental factors of EUA prices (Mansanet-Bataller, Chevallier, \& Chèze, 2007; Keppler \& Mansanet-Bataller, 2010; Fezzi \& Bunn, 2009; Chevallier, 2011).
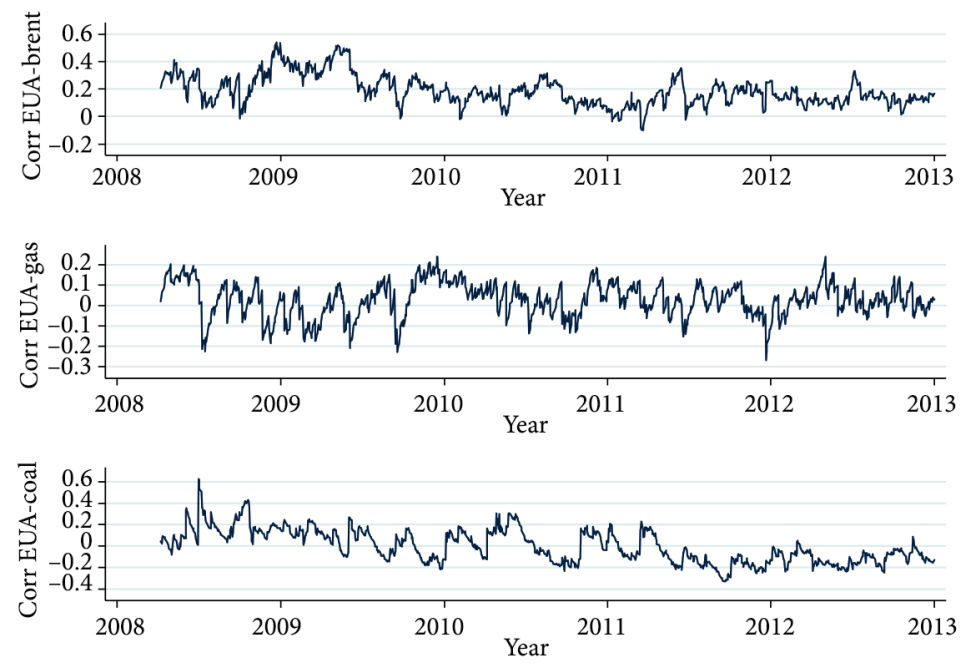

Figure 6. Dynamic correlation between the daily log returns of EUA and the energy futures from the phase II of EU ETS

One possible explanation for such a result is that after the 2008 economic crisis the total real emission fell, hence a demand for the allowances. The reduction triggered by economic slowdown was far more than the annual reduction of the cap, which is $6.5 \%$ less compared to the 2005 emission level. This led to a large and growing surplus of unused allowances throughout the whole period and prices of the EUA dipped. Such influence exceeded the influence brought by the energy markets, which might be the major reason why the correlation between the EUA and all energy prices decreased during the second period of the EU ETS. 


\subsection{Phase III of EU ETS}

Phase III also has changes. Firstly, instead of national caps, a single, EU-wide cap on emission is applied and the cap is reduced by $1.74 \%$ each year. Secondly, while the vast majority of emission allowances were given away for free by governments previously, auctioning is the main method of allocation since the phase 3 . Thirdly, more than $40 \%$ of allowance in the system was auctioned in 2013 and this share will grow progressively in the following years. The changes make the system more market-driven.

Table 5. Estimation of asymmetric BEKK $(1,1)$ model to the daily log returns of EUA and brent, natural gas, coal from $2 / 1 / 2013$ to $17 / 7 / 2018$ for 1383 observations

\begin{tabular}{|c|c|c|c|c|c|c|}
\hline \multirow{2}{*}{ Parameters } & \multicolumn{6}{|c|}{$\begin{array}{c}\text { Estimations } \\
\text { (Standard Errors) }\end{array}$} \\
\hline & \multicolumn{2}{|c|}{ EUA-Brent } & \multicolumn{2}{|c|}{ EUA-gas } & \multicolumn{2}{|c|}{ EUA-coal } \\
\hline \multirow{2}{*}{$C_{0}$} & $\begin{array}{l}0.2566^{* * *} \\
(0.0649)\end{array}$ & & $\begin{array}{l}0.2855^{* * *} \\
(0.0611)\end{array}$ & & $\begin{array}{l}0.5800^{* * *} \\
(0.1877)\end{array}$ & \\
\hline & $\begin{array}{l}-0.0429 \\
(0.0534)\end{array}$ & $\begin{array}{l}0.0945^{\star *} \\
(0.0408)\end{array}$ & $\begin{array}{c}0.0111 \\
(0.1022)\end{array}$ & $\begin{array}{l}0.1820^{* * *} \\
(0.0559)\end{array}$ & $\begin{array}{c}0.1337 \\
(0.1565)\end{array}$ & $\begin{array}{l}0.4630^{* * *} \\
(0.0950)\end{array}$ \\
\hline \multirow{2}{*}{$\mathbf{A}_{1}$} & $\begin{array}{l}0.2952^{* * *} \\
(0.0297)\end{array}$ & $\begin{array}{c}0.0008 \\
(0.0081)\end{array}$ & $\begin{array}{c}0.3036^{* * *} \\
(0.0293)\end{array}$ & $\begin{array}{l}-0.0038 \\
(0.0128)\end{array}$ & $\begin{array}{l}0.4301^{* * *} \\
(0.0998)\end{array}$ & $\begin{array}{l}-0.0179 \\
(0.0143)\end{array}$ \\
\hline & $\begin{array}{c}0.0071 \\
(0.0250)\end{array}$ & $\begin{array}{l}0.0840^{* *} \\
(0.0425)\end{array}$ & $\begin{array}{l}-0.0230 \\
(0.0383)\end{array}$ & $\begin{array}{c}-0.0814^{* *} \\
(0.0384)\end{array}$ & $\begin{array}{l}0.3708^{* *} \\
(0.1869)\end{array}$ & $\begin{array}{l}0.6143^{* * *} \\
(0.1271)\end{array}$ \\
\hline \multirow{2}{*}{$\mathbf{B}_{1}$} & $\begin{array}{l}0.9525^{* * *} \\
(0.0084)\end{array}$ & $\begin{array}{c}0.0005 \\
(0.0022)\end{array}$ & $\begin{array}{l}0.9475^{* * *} \\
(0.0087)\end{array}$ & $\begin{array}{c}0.0016 \\
(0.0039)\end{array}$ & $\begin{array}{l}0.9536^{* * *} \\
(0.0101)\end{array}$ & $\begin{array}{c}0.0022 \\
(0.0025)\end{array}$ \\
\hline & $\begin{array}{c}0.0058 \\
(0.0055)\end{array}$ & $\begin{array}{l}0.9792^{* * *} \\
(0.0045)\end{array}$ & $\begin{array}{c}0.0051 \\
(0.0098)\end{array}$ & $\begin{array}{l}0.9821^{* * *} \\
(0.0049)\end{array}$ & $\begin{array}{l}-0.1013 \\
(0.1057)\end{array}$ & $\begin{array}{l}0.7988^{* * *} \\
(0.0226)\end{array}$ \\
\hline \multirow{2}{*}{$D_{1}$} & $\begin{array}{c}0.0174 \\
(0.0812)\end{array}$ & $\begin{array}{l}-0.0037 \\
(0.0092)\end{array}$ & $\begin{array}{c}0.0643 \\
(0.1135)\end{array}$ & $\begin{array}{l}-0.0359^{* *} \\
(0.0131)\end{array}$ & $\begin{array}{l}-0.4293^{*} \\
(0.1326)\end{array}$ & $\begin{array}{l}-0.0434^{\star} \\
(0.0234)\end{array}$ \\
\hline & $\begin{array}{c}0.0180 \\
(0.0394)\end{array}$ & $\begin{array}{l}0.2674^{* * *} \\
(0.0314)\end{array}$ & $\begin{array}{l}-0.0481 \\
(0.0497)\end{array}$ & $\begin{array}{l}0.2138^{* * *} \\
(0.0368)\end{array}$ & $\begin{array}{c}0.1634 \\
(0.2231)\end{array}$ & $\begin{array}{l}0.4431^{* * *} \\
(0.1453)\end{array}$ \\
\hline $\begin{array}{c}\text { Log } \\
\text { Likelihood }\end{array}$ & \multicolumn{2}{|c|}{-6012.680} & \multicolumn{2}{|c|}{-6187.641} & \multicolumn{2}{|c|}{-4958.246} \\
\hline
\end{tabular}

${ }^{\star},{ }^{* *}$ and ${ }^{* *}$ represent the statistics are significant in the confidence level of $10 \%, 5 \%$ and $1 \%$.

Table 5 presents the estimation results of asymmetric BEKK model for the third phase. The high persistence still exists in the volatility of the EUA price and energy market itself, and we still cannot find volatility spillover between them (the coefficients $\beta_{12}$ and $\beta_{21}$ in the $B$ matrix are not significant). Therefore, the connectedness between the EUA price and energy markets weakened during the third phase of EU ETS, since there is no volatility spillover between them. The EUA price was not asymmetric effect ( $d_{11}$ in EUA-Brent, EUA-gas, and EUA-coal are non-significant). One potential explanation is that the EU ETS is regulated to extend by the European Commission, so that investors do not pay attention to price signals (good or bad news), but rather pay more attention to policy shift with EU ETS. Brent oil, natural gas, and coal all have positive asymmetry, i.e., negative news will increase its own volatility, which is due to most energy commodities do not have the hedging function. 

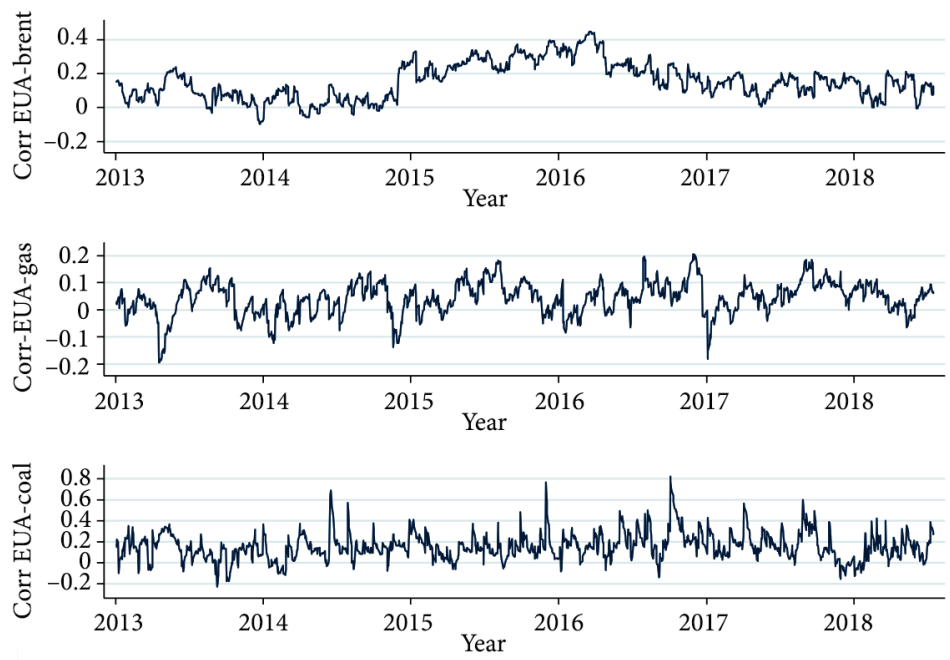

Figure 7. Dynamic correlation between the daily log returns of EUA and the energy futures from the phase III of EU ETS

Figure 7 shows the dynamic correlation between the EUA and all energy markets from 2013 to 2018. The correlation is still volatile for the EUA and coal, and the EUA and the natural gas. However, the correlation between EUA and Brent oil is relatively stable. In addition to the correlation between Brent oil and EUA, coal and EUA the other group is basically related to fluctuations around 0 (The mean value of correlation coefficient between EUA and natural gas is 0.004 ). The conclusion should be similar to the second phase that after the economic crisis, the correlation between the EUA and the Brent oil, natural gas and coal decreased because of over-allocation caused by the economic slowdown. In the beginning of 2013, the correlation between EUA and natural gas and EUA and coal showed similar characteristics of instability, and the correlation between EUA and crude oil was relatively independent during this period.

\section{Discussion}

Measuring volatility spillover between the carbon market and other financial market has emerged in recent researches (Mansanet-Bataller \& Soriano, 2009; Reboredo, 2014; Dhamija, Yadav, \& Jain, 2016; Zhang \& Sun, 2016; Ji, Zhang, \& Geng, 2018). From the financial perspective, if there is a risk transfer between different financial markets, i.e., volatility spillover effects, it can be considered that the activities on financial market are effective, rather than being intervened. Hence, this paper find a little evidence to prove that the establishment of the EU ETS can successfully limitation and influence energy demand, promote energy technology evolution, and ultimately achieve the goal of reducing the carbon emissions and improve energy efficiency (Only in phase II of EU ETS, the EUA price has a volatility spillover on Brent oil, the natural gas has a volatility spillover on EU ETS). Meanwhile, the existing literature still has a little consensus about whether there is volatility spillover between the EU 
ETS and the energy markets, the reason may be that the EU ETS has modified trading rules and commodities in each phases (Reboredo, 2014; Nava, Meleo, Cassetta, \& Morelli, 2018), from the simultaneous sale of spot and futures to the sale of only futures on EUA.

In addition, the coal market is often overlooked due to the share of coal in primary energy consumption in Europe has already fallen to the bottom. Based on the previous research, therefore, this paper carried out the following work. Firstly, this paper considers not only the oil and gas market, but also the coal market, and employs the bivariate asymmetric BEKK model to measure volatility spillovers and risk transfer. Secondly, this paper takes the dynamic correlation between the EUA and energy markets into account. It provides us a dynamic perspective to show the evolution of the correlation between them. Thirdly, this paper consider three phases of the EU ETS to find out the long-term correlation and how it fluctuations during different periods. Finally, the asymmetric effect on volatility spillover between EU ETS and energy markets is considered.

There is a volatility spillover from the natural gas to EUA and the EUA to Brent oil in the second Phase of EU ETS. Natural gas is considered to be an efficient and clean energy source, and the carbon emissions are lower than coal and oil. So the natural gas will have an impact on the carbon market. There was no volatility spillover effect between the EU ETS and coal. A possible explanation is that it takes time for energy enterprises to change energy using strategies and decide whether new emission-cutting technology should be implemented. They can't revolution the strategies on coal application immediately, so the prices of EUA may not co-move with the prices of coal. Moreover, the dynamic correlation is obtained from the results of asymmetric BEKK models, providing us with a dynamic perspective to analyze the evolution of the relationship between the EUA and energy markets. And only the asymmetry of the EUA's own volatilities persists in the three phases of the EU ETS.

In general, the volatility spillover effect between the EUA price and three energy markets among the three phases of the EU ETS is hardly significant, which may indicate that the economic downturn cut the real emission demand far more than the reduction of the cap throughout the second phase and the first two years of phase III. Such influence exceeded the influence brought by the energy markets. The third phase has a similar conclusion with the second phase. From a stability point of view, the fluctuations in the dynamic correlation coefficient between EU ETS and Brent oil may be the smallest, indicating that crude oil has always been the focus of the market compared to natural gas and coal.

\section{Conclusions}

For market operators, policymakers and investors, it is vital to excavate the correlation between the carbon market and the energy market and its potential volatility spillover effects. Consequently, this paper mainly studies the volatility spillover effect between EUA and energy prices (Brent oil, natural gas and coal). The empirical results are as follows: only in phase II of EU ETS, the EUA has a significant volatility spillover effect on Brent oil. In other phases, the volatility spillover effect does not exist. The EUA has an asymmetric effect in its own volatility in the first and second phases, that is, bad news leads to greater volatilities. However, the volatility of energy itself is asymmetric in all phases. Besides, there is a relatively 
stable positive correlation between EUA and Brent oil, natural gas in all phases. After the Global Financial Crisis in 2008, the correlation between EUA and energy markets became more volatile than that before the economic downturn and the coefficients of correlation decreased in second phase. However, due to the constraints on time scale and data, the weaker volatility spillover and unstable correlation between carbon market and energy market is not a final standpoint. Some results are counterintuitive since carbon emission is closely associated with energy, especially fossil fuel considered in this paper, hence the demand and prices of the emission allowance only have a little connection. Therefore, the fact that the economic crisis may reduced a large amount of emission more than the annual reduction of the cap should be taken into consideration, and that the energy companies cannot transform energy consumption structures in a short period.

The above conclusions provide stakeholders the following enlightenment. First of all, both the carbon and the energy markets have strong financial attributes in EU, and the volatility of the energy market has significant asymmetry, while the asymmetricity of the carbon market has variables, so the carbon market investors need to pay close attention to these characteristics on energy to avoid extreme investment risks. Secondly, the dynamic correlation and volatility spillover of carbon and energy markets suggest that industrial and energy enterprises not only need to adjust their energy consumption structure, but also need to predict the decline in carbon demand based on macroeconomic conditions to achieve optimal carbon emission reduction and technology upgrade strategies. Lastly, compared with developing countries, the proportion of coal in the primary energy consumption structure of the EU is relatively low. Therefore, the early futures commodities established in the EU ETS are mainly based on carbon emission allowance caused by oil and natural gas. For countries and regions that intend to establish an emissions trading scheme, the primary energy consumption structure is a crucial reference for the carbon market and its commodities type.

Further research is necessary, although the impact of EU ETS on the economy is not limited on financial sector, but financial market as the main carrier of EU ETS will remain the focus of research in the future. And research on financial markets may focuses on modeling, forecasting, and economic implications, but the above concerns should be based on the time scale and availability of the data. Consequently, the use of high-frequency data may lead to a more accurate examination of the interaction between the carbon market and the energy market. Subsequently, with the methods such as DECO-FIGARCH model and wavelet coherence, more stylized facts in the volatility between energy market and carbon market including long memory, persistence and structural breaks can be considered. In addition, the variance between carbon markets and energy markets in different countries are also issues that need urgent attention, reflecting regional differences.

\section{Acknowledgements}

The authors would like to thank Biao Zheng, Lihua Ma and Jian Yu for their helpful comments on the manuscript. 


\section{Funding}

This work was supported by the $<$ National Natural Science Foundation of China $>$ under Grant [71673250]; <Zhejiang Provincial Natural Science Foundation of China-Outstanding Youth Foundation> under Grant [LR18G030001]; <MOE Major Project of Key Research Institute of Humanities and Social Sciences in Universities > under Grant [14JJD770019]; <Zhejiang Provincial Philosophy and Social Science Foundation> under Grant [18NDJC184YB].

\section{Author contributions}

Yufeng CHEN conceived the study and was responsible for the design and development of the data analysis. Yufeng CHEN, Fang QU and Wenqi LI were responsible for data collection and explanation. Yufeng CHEN and Fang QU wrote the first draft of the article, and Minghui CHEN responsible for text calibration.

\section{Disclosure statement}

We confirm that the manuscript has been read and approved by all named authors and that there are no competing financial, professional, or personal interests from other parties.

\section{References}

Alberola, E., Chevallier, J., \& Chèze, B. (2008a). Price drivers and structural breaks in European carbon prices 2005-2007. Energy Policy, 36(2), 787-797. https://doi.org/10.1016/j.enpol.2007.10.029

Alberola, E., Chevallier, J., \& Chèze, B. (2008b). The EU emissions trading scheme: The effects of industrial production and $\mathrm{CO}_{2}$ emissions on carbon prices. Economie Internationale, 116(4), 93-126. https://doi.org/10.2139/ssrn.1133139

Aatola, P., Ollikainen, M., \& Toppinen, A. (2013). Price determination in the EU ETS market: Theory and econometric analysis with market fundamentals. Energy Economics, 36, 380-395.

https://doi.org/10.1016/j.eneco.2012.09.009

Akar, C. (2017). Average spillover behavior of Turkish exchange market volatility. In Çilingirtürk, A. M., Albrychiewicz Słocinsk, A., \& Bülent Bali, B. (Ed.), Economics, Management \& Econometrics (pp. 123-135). IJOPEC Publication.

Benz, E., \& Trück, S. (2009). Modeling the price dynamics of CO2 emission allowances. Energy Economics, 31(1), 4-15. https://doi.org/10.1016/j.eneco.2008.07.003

Baele, L. (2005). Volatility spillover effects in European equity markets. The Journal of Financial and Quantitative Analysis, 40(2), 373-401. https://doi.org/10.1083/jcb.200608066

Bubák, V., Kocenda, E., \& Zikes, F. (2011). Volatility transmission in emerging European foreign exchange markets. Journal of Banking \& Finance, 35, 2829-2841.

https://doi.org/10.1016/j.jbankfin.2011.03.012

Campiglio, E. (2016). Beyond carbon pricing: The role of banking and monetary policy in financing the transition to a low-carbon economy. Ecological Economics, 121, 220-230.

https://doi.org/10.1016/j.ecolecon.2015.03.020

Chevallier, J. (2011). A model of carbon price interactions with macroeconomic and energy dynamics. Energy Economics, 33(6), 1295-1312. https://doi.org/10.1016/j.eneco.2011.07.012 
Chen, Y., Li, W., \& Qu, F. (2019). Dynamic asymmetric spillovers and volatility interdependence on China's stock market. Physica A: Statistical Mechanics and its Applications, 523, 825-838. https://doi.org/10.1016/j.physa.2019.02.021

Conrad, C., Rittler, D., \& Rotfuß, W. (2012). Modeling and explaining the dynamics of European Union Allowance prices at high-frequency. Energy Economics, 34(1), 316-326. https://doi.org/10.1016/j.eneco.2011.02.011

Cui, Q., Li, Y., Wei, Y. M., Cui, Q., Li, Y., \& Wei, Y. M. (2017). Exploring the impacts of EU ETS on the pollution abatement costs of european airlines: an application of network environmental production function. Transport Policy, 60, 131-142. https://doi.org/10.1016/j.tranpol.2017.09.013

Dhamija, A. K., Yadav, S. S., \& Jain, P. K. (2016). Forecasting volatility of carbon under EU ETS: a multi-phase study. Environmental Economics \& Policy Studies, 19(2), 1-37. https://doi.org/10.1007/s10018-016-0155-4

Diebold, F. X., \& Yilmaz, K. (2009). Measuring financial asset return and volatility spillovers, with application to global equity markets. Economic Journal, 119(534), 158-171. https://doi.org/10.1111/j.1468-0297.2008.02208.x

Diebold, F. X., \& Yilmaz, K. (2012). Better to give than to receive: Predictive directional measurement of volatility spillovers. International Journal of Forecasting, 28(1), 57-66. https://doi.org/10.1016/j.ijforecast.2011.02.006

Du, X., Yu, C. L., \& Hayes, D. J. (2011). Speculation and volatility spillover in the crude oil and agricultural commodity markets: A Bayesian analysis. Energy Economics, 33(3), 497-503. https://doi.org/10.1016/j.eneco.2010.12.015

Dutta, A., Bouri, E., \& Noor, M. H. (2018). Return and volatility linkages between $\mathrm{CO}_{2}$ emission and clean energy stock prices. Energy, 164(1), 803-810. https://doi.org/10.1016/j.energy.2018.09.055

Efimova, O., \& Serletis, A. (2014). Energy markets volatility modelling using garch. Energy Economics, 43, 264-273. https://doi.org/10.1016/j.eneco.2014.02.018

Engle, R. F., \& Kroner, K. F. (1995). Multivariate simultaneous generalized arch. Econometric Theory, 11(1), 122-150. https://doi.org/10.1017/S0266466600009063

Ellerman, A. D. (2008). The EU's emissions trading scheme: a prototype global system? Social Science Electronic Publishing.

Ellerman, A. D., Convery, F. J., \& De Perthuis, C. (2010). Pricing carbon: the European Union emissions trading scheme. Cambridge University Press.

Eugenia Sanin, M., Violante, F., \& Mansanet-Bataller, M. (2015). Understanding volatility dynamics in the EU-ETS market. Energy Policy, 82(1), 321-331. https://doi.org/10.1016/j.enpol.2015.02.024

Fezzi, C., \& Bunn, D. W. (2009). Structural interactions of European carbon trading and energy markets. The Journal of Energy Markets, 2(4), 53-69. https://doi.org/10.21314/JEM.2009.034

Fan, Y., Jia, J. J., Wang, X., \& Xu, J. H. (2017). What policy adjustments in the EU ETS truly affected the carbon prices? Energy Policy, 103(1), 145-164. https://doi.org/10.1016/j.enpol.2017.01.008

Glosten, L. R., Jagannathan, R., \& Runkle, D. E. (1993). On the relation between the expected value and the volatility of the nominal excess return on stocks. The Journal of Finance, 48(5), 1779-1801. https://doi.org/10.1111/j.1540-6261.1993.tb05128.x.

Hamao, Y., Masulis, R. W., \& Ng, V. (1990). Correlations in price changes and volatility across international stock markets. Review of Financial Studies, 3(2), 281-307. https://doi.org/10.1093/rfs/3.2.281

Hu, J., Crijns-Graus, W., Long, L., \& Gilbert, A. (2015). Ex-ante evaluation of EU ETS during 2013-2030: EU-internal abatement. Energy Policy, 77(1), 152-163. https://doi.org/10.1016/j.enpol.2014.11.023

Hong, Y. (2001). A test for volatility spillover with application to exchange rates. Journal of Econometrics, 103(1), 183-224. https://doi.org/10.1016/S0304-4076(01)00043-4 
Ibrahim, B. M., \& Kalaitzoglou, I. A. (2016). Why do carbon prices and price volatility change? Journal of Banking and Finance, 63, 76-94. https://doi.org/10.1016/j.jbankfin.2015.11.004

Ji, Q., Zhang, D., \& Geng, J. B. (2018). Information linkage, dynamic spillovers in prices and volatility between the carbon and energy markets. Journal of Cleaner Production, 198, 972-978. https://doi.org/10.1016/j.jclepro.2018.07.126

Jiménez-Rodríguez, R. (2019). What happens to the relationship between EU allowances prices and stock market indices in Europe? Energy Economics, 81(1), 13-24. https://doi.org/10.1016/j.eneco.2019.03.002

Kanamura, T. (2016). Role of carbon swap trading and energy prices in price correlations and volatilities between carbon markets. Energy Economics, 54(1), 204-212. https://doi.org/10.1016/j.eneco.2015.10.016

Keppler, J. H., \& Mansanet-Bataller, M. (2010). Causalities between $\mathrm{CO}_{2}$, electricity, and other energy variables during phase I and phase II of the EU ETS. Energy Policy, 38(7), 3329-3341. https://doi.org/10.1016/j.enpol.2010.02.004

Lin, B., \& Jia, Z. (2017). The impact of emission trading scheme (ETS) and the choice of coverage industry in ETS: a case study in China. Applied Energy, 205(1), 1512-1527. https://doi.org/10.1016/j.apenergy.2017.08.098

Lutz, B. J., Pigorsch, U., \& Rotfuß, W. (2013). Nonlinearity in cap-and-trade systems: The EUA price and its fundamentals. Energy Economics, 40(1), 222-232. https://doi.org/10.1016/j.eneco.2013.05.022

Mansanet-Bataller, M., Pardo, A., \& Valor, E. (2007). $\mathrm{CO}_{2}$ prices, energy and weather. Energy Journal, 28(3), 73-92. https://doi.org/10.5547/ISSN0195-6574-EJ-Vol28-No3-5

Mansanet-Bataller, M., \& Soriano, P. (2009). Volatility transmission in the $\mathrm{CO}_{2}$ and energy markets. In 2009 6th International Conference on the European Energy Market. IEEE.

Nava, C. R., Meleo, L., Cassetta, E., \& Morelli, G. (2018). The impact of the EU-ETS on the aviation sector: competitive effects of abatement efforts by airlines. Transportation Research Part A: Policy and Practice, 113, 20-34. https://doi.org/10.1016/j.tra.2018.03.032

Parsons, J. E., Ellerman, A. D., \& Feilhauer, S. (2009). Designing a U.S. Market for $\mathrm{CO}_{2}$. Journal of Applied Corporate Finance, 21(1), 79-86. https://doi.org/10.1111/j.1745-6622.2009.00218.x

Reboredo, J. C. (2014). Volatility spillovers between the oil market and the European Union carbon emission market. Economic Modelling, 36(1), 229-234. https://doi.org/10.1016/j.econmod.2013.09.039

Soliman, A. M., \& Nasir, M. A. (2019). Association between the energy and emission prices: An analysis of EU emission trading system. Resources Policy, 61(1), 369-374. https://doi.org/10.1016/j.resourpol.2018.12.005

Wang, Y., \& Guo, Z. (2018). The dynamic spillover between carbon and energy markets: New evidence. Energy, 149, 24-33. https://doi.org/10.1016/j.energy.2018.01.145

Xu, L., Deng, S. J., \& Thomas, V. M. (2016). Carbon emission permit price volatility reduction through financial options. Energy Economics, 53(1), 248-260. https://doi.org/10.1016/j.eneco.2014.06.001

Zhang, Y. J., \& Wei, Y. M. (2010). An overview of current research on EU ETS: evidence from its operating mechanism and economic effect. Applied Energy, 87(6), 1804-1814.

Zhang, Y. J., \& Sun, Y. F. (2016). The dynamic volatility spillover between European carbon trading market and fossil energy market. Journal of Cleaner Production, 112, 2654-2663. https://doi.org/10.1016/j.jclepro.2015.09.118 